\title{
Risk Factors and Prevention of Paediatric Burns in Jamaica
}

\author{
MV Vincent ${ }^{1,2}$, SE Dundas-Byles ${ }^{2}$, ND Duncan ${ }^{2}$
}

\begin{abstract}
Purpose: This study aimed to establish if common international paediatric burn demographics were also true for Jamaican children and to propose preventive measures for paediatric burns in Jamaica, based on the collation and analysis of data at one paediatric surgery referral centre.

Methods: Children presenting with burns over a four-year period (January 2010 to December 2013) were prospectively followed to discharge and their demographics and clinical details collated in an effort to establish preventive guidelines.

Results: There were 52 children ranging in age from one month to 11 years. Common international burn demographics were evident locally. Local practices such as: burning household garbage and leaving children unsupervised at home with lit candles in homes with no electricity, were major risk factors linked to paediatric burns and burnt deaths.

Conclusion: The most vulnerable of children-toddlers age two years and under were most at risk of burn injuries sustained at home from preventable causes. Local preventive measures must focus on parental education on home safety, supervision of older children; particularly older boys at play and their education on the dangers associated with playing with fire.
\end{abstract}

Keywords: Burns, Jamaica, Paediatric

\section{Factores de Riesgo y Prevención de Quemaduras Pediátricas en Jamaica MV Vincent ${ }^{1,2}$, SE Dundas-Byles ${ }^{2}$, ND Duncan ${ }^{2}$}

\begin{abstract}
RESUMEN
Propósito: Este estudio tuvo como objetivo determinar si las estadísticas demográficas internacionales sobre quemaduras pediátricas eran también ciertas para los niños jamaicanos, y proponer medidas preventivas para las quemaduras pediátricas en Jamaica, basadas en la compilación y análisis de datos de un centro de referencia de cirugía pediátrica.

Métodos: Niños con quemaduras durante un período de cuatro años (enero de 2010 a diciembre de 2013) fueron seguidos prospectivamente hasta el alta, y sus datos demográficos y detalles clínicos fueron compilados en un esfuerzo por establecer pautas de prevención.

Resultados: Se estudiaron 52 niños cuyas edades oscilaron de un mes a 11 años de edad. Las estadísticas demográficos internacionales comunes sobre quemaduras eran localmente evidentes. Prácticas locales tales como quemar la basura de la casa y dejar a los niños sin supervisión en la casa con velas encendidas cuando no hay electricidad, fueron factores de riesgo principales relacionados con las quemaduras pediátricas y las muertes por quemaduras.

Conclusión: Los niños más vulnerables - los pequeños de dos años o menores - corren principalmente el riesgo de heridas por quemaduras sufridas en la casa por causas prevenibles. Las medidas preventivas locales deben centrarse en educar a los padres en torno a la seguridad de la casa, y supervisar a los niños mayores - particularmente a los niños mayores que juegan y los peligros asociados con jugar con fuego.
\end{abstract}

Palabras claves: Quemaduras, Jamaica, Pediátrico

West Indian Med J 2017; 66 (1): 128

From: ${ }^{1}$ Department of Surgery, The Queen Elizabeth Hospital, Barbados and ${ }^{2}$ Department of Surgery, Anaesthesia and Intensive Care, The University Hospital of the West Indies, Kingston 7, Jamaica, West Indies.
Correspondence: Dr MV Vincent, The Queen Elizabeth Hospital, Martindales Road, St Michael, Barbados. Fax: 1 (246) 429-5374; email: michvincent@yahoo.com 


\section{INTRODUCTION}

Burn injuries are a leading cause of paediatric admissions worldwide $(1,2)$ and contribute to approximately one-fifth of the admissions for trauma at our Institution (3). It is also associated with a significant economic burden due to the need for prolonged therapies and multiple dressings $(1,2,4)$. This can be particularly challenging for developing countries like Jamaica.

The aim of this study was to establish if some of the common paediatric burn demographics seen internationally, for example, the highest incidence in toddlers - in whom scald burns predominate and a male preponderance were also true for Jamaican children. Secondly, we wanted to identify the mechanisms and social circumstances surrounding paediatric burn injuries in Jamaica in order to help identify local preventive measures. This is extremely important as preventive measures proposed by the other international studies may not be relevant for Jamaica. For example, the widespread use of candles in homes with no electricity supply and the practice of deliberately lighting fires for the purpose of burning household garbage are examples of local factors repeatedly linked to paediatric burns and burn deaths in Jamaica, as reflected from this study, the first of its kind. The toddler is also most at risk of child abuse and burn injuries need to be carefully evaluated with this in mind.

\section{SUBJECTS AND METHODS}

Beginning January 2010 to December 2013, all children with burn injuries admitted to the Paediatric Surgical Unit at The University Hospital of the West Indies (UHWI) had their data recorded in a set database. Inclusion criteria were all paediatric patients (16 years and under) presenting with burn injuries that were admitted to the paediatric surgical ward. Data were collected on patients': age, gender, aetiology and circumstances surrounding the burn injury, total body surface area [TBSA] affected, and location and depth/degree of the burn wound. The data were analysed using descriptive statistics. Throughout the four-year study period, all children were referred to the medical social worker to ensure no missed cases of child abuse. The UHWI is a major teaching hospital located in the capital of Jamaica offering specialist services at a supplemented cost to the Jamaican public and surrounding Caribbean Islands. It is one of two centres in urban Jamaica offering paediatric surgical services. All children with burns injuries admitted to the UHWI are initially assessed in the Accident and Emergency Department and subsequently referred to the paediatric surgical team.

\section{RESULTS}

Over the four-year study period, a total of 52 children were admitted to the surgical ward with burn injuries. The annual number of paediatric burn admissions was fairly constant over the study period ranging from 11 to 17 admissions per year, with a mean of $13(\mathrm{SD}=2.0)$.
The children ranged in age from one month to 11 years, mean age of three years $(\mathrm{SD}=2.99)$. The majority were boys $(65 \%)$. The most common age group affected were toddlers aged two years and under $(63 \%)$, and in this group boys also outnumbered girls $(2: 1)$. Toddlers were more likely to be affected by scald burns from spilted hot water or feeds, whereas in the older age group (5 years and older) flame burns predominated (Table 1). There were 12 children sustaining flame burns (23\%). Flame burns in boys (7) were usually sustained while experimenting with fire at play, whereas in girls (5) it was usually because they were the victims of child abuse - placed on a hot stove by mother (1 girl, 2 years old), victims of neglect after being left at home alone at night with lit candles in a home with no electricity supply ( 2 girls, 2 months and 3 years, respectively). There were no cases of electrical burns.

Table 1: Type of burn injury in relation to age group

\begin{tabular}{lll}
\hline Age group & No of children (percentage) & Type of burn injury \\
\hline 1 month -2 years & $33(63 \%)$ & Scald 24 \\
& - Hot water 17 \\
& - Hot tea/drink 3 \\
& - Hot foods 4 \\
& & Flame 4 \\
& & Contact 5 \\
& & - hot iron 1 \\
& & - hot plastic 1 \\
& & - hot motor bike 1 \\
& & - hot cooking pot 2 \\
& & Scalds 3 \\
& & Flame 3 \\
& & Scalds 8 \\
5 months -5 years -11 years & $6(12 \%)$ & Flame 5 \\
\hline
\end{tabular}

Children with flame burns often required surgical intervention under general anaesthesia (3 children). These children tended to have deeper burns and a larger total body surface area (TBSA) affected. The child with the greatest TBSA burn was a three-year-old girl sustaining $40 \%$ flame burns after she was left with other siblings unsupervised at home with a lighted candle. She required three surgical procedures (grafting and wound debridement) under general anaesthesia. Surgical interventions (grafting, escharotomy, fasciotomy, and/or wound debridement) under general anaesthesia were also required in two other children affected by flame burns. The average affected TBSA for contact burns was $2 \%$ [SD = $0.02]$, scald burns averaging $10 \%$ [SD $=0.07]$ and flame burns averaging $20 \%$ [SD $=0.11]$.

Hospital stay ranged from one day to 70 days (median $=$ 7 days), with over $42 \%$ of the children spending more than one week in hospital (Table 2).

The children having the longest hospital stay were usually those sustaining flame burns. The median stay for children with contact, scald and flame burns were four days, six days and 23 days, respectively. 
Table 2: Burn demographic data summarized

\begin{tabular}{|c|c|c|c|c|}
\hline $\begin{array}{l}\text { Length of } \\
\text { hospital } \\
\text { stay (days) }\end{array}$ & $\begin{array}{c}\text { No. of } \\
\text { patients }\end{array}$ & $\begin{array}{l}\text { Type of burn } \\
(\#)\end{array}$ & $\begin{array}{c}\text { No. of } \\
\text { children } \\
\text { with third } \\
\text { degree burns }\end{array}$ & $\begin{array}{c}\text { No. of surgica } \\
\text { interventions } \\
\text { (No. of } \\
\text { children) }\end{array}$ \\
\hline \multirow[t]{3}{*}{ 1-7 days } & \multirow[t]{3}{*}{30} & Scalds (24) & 1 & \multirow{3}{*}{0} \\
\hline & & Flame (3) & 0 & \\
\hline & & Contact (3) & 0 & \\
\hline \multirow[t]{3}{*}{ 8-14 days } & \multirow[t]{3}{*}{9} & Scalds (7) & 1 & \multirow{3}{*}{0} \\
\hline & & Flame (1) & 0 & \\
\hline & & Contact (1) & 0 & \\
\hline \multirow[t]{3}{*}{ 15-21 days } & \multirow[t]{3}{*}{2} & Scalds (1) & 0 & \multirow{3}{*}{0} \\
\hline & & Flame (1) & 0 & \\
\hline & & Contact (1) & 0 & \\
\hline \multirow[t]{2}{*}{ 22-30 days } & \multirow[t]{2}{*}{8} & Scalds (3) & 0 & \multirow[b]{2}{*}{0} \\
\hline & & Flame (4) & 0 & \\
\hline \multirow[t]{2}{*}{$>30$ days } & \multirow[t]{2}{*}{3} & \multirow[t]{2}{*}{ Flame (3) } & \multirow[t]{2}{*}{3} & $2-(2$ children $)$ \\
\hline & & & & $1-(1$ child $)$ \\
\hline
\end{tabular}

Children were not discharged from the unit, until the following criteria were met: child abuse excluded by both the admitting surgeon and social worker, parents/guardians interviewed by social worker and taught safety prevention measures, the home visited by the social worker in specific cases and deemed safe for the child's return, the burn wound no longer at risk of wound infection, parents/guardians assessed as competent by the nursing staff at continuing any further wound care at home and follow-up visits arranged.

Most children admitted had superficial partial thickness burns (46, 88\%). Two had deep partial thickness burns, from flame burns. Four had a combination of superficial and deep partial thickness burns, three of these from flame burns and one from spilled hot water.

In the majority of children $(41,79 \%)$, more than one body part was affected by the burn injury. The most common body part affected was the upper limbs ( 27 cases), followed by the torso (26 cases), face and neck (23 cases), lower limbs (23 cases) and perineum (six cases). Of the 23 children suffering burns to the face and neck, four needed a referral to the ophthalmologists based on the history of the burn injury and burn wound location, with two being diagnosed and treated for first-degree corneal burns.

There were five cases of delayed presentation, four delayed by just under 24 hours and one by two days. In all five cases of delayed presentation, child abuse was specifically excluded as being the causation of the burn injury. The reason for the delay in presentation was due to the location of the home in rural Jamaica and lack of transport (two cases), and the initial trial of home remedies (three cases). In the latter group, one parent was, unfortunately, using a harmful agent [hydrogen peroxide] to cleanse a three-year-old girl's 3\% flame burn wound to the mons pubis and both thighs, prior to seeking medical attention.
Child abuse was suspected in a 13-month-old girl who presented with an $18 \%$ scald burn to the chest and upper abdomen, with suspiciously well-demarcated borders. Abuse was subsequently excluded after interviews with parents and family members and visits to the home by the social worker. There was, however, one confirmed case of child abuse in a twoyear-old girl sustaining $25 \%$ flame burn wounds to the buttocks, lower back, left thigh and right forearm after being placed on a hot stove by her mom, who was acutely mentally disturbed.

\section{DISCUSSION}

Internationally, children aged two years and younger are at greatest risk of burn injuries $(1,2,4,5-12)$. Contributory factors include, their relative lack of independence, the fact that these injuries tend to occur at home and also because toddlers are naturally curious as they are just beginning to walk and explore their environment $(1,2,5)$. This international observation is borne out in this Jamaican study where $58 \%$ of burns occurred in toddlers (children two years and younger), occurred at home and were usually due to the toddler pulling containers of hot liquids onto themselves.

Risk-taking behaviour in older boys aged $4-9$ years is also internationally observed and is due to the fact that boys are more likely than girls to seek out and use flammable substances while at play $(1,2,4,9)$. This observation is also apparent in Jamaican boys. Of the twelve children sustaining flame burns the minority (five) were girls, only two of whom were experimenting with fire, one playing with a lighter at home, the other running around a fire lit at home to burn garbage. The other three girls were the victims of child abuse [one girl] and house fires [two girls].

Flame burns tend to account for the higher TBSA burns and are also responsible for the majority of burn deaths in children worldwide $(1,13)$ as was noted during this study. Locally these deaths often occur as a direct result of children being left at home alone with lit candles in homes without an electricity supply or due to arson from persons deliberately setting homes on fire (14). The two children who were victims of the former dangerous practice in this study were fortunate since their other two siblings were burnt to death in the house fire.

The majority of burn injuries in this series occurred in the home and were preventable scald burns from hot water [Table 1]. This pattern is repeatedly observed in both developed and developing countries alike $(1,2,4,5,7-9,11,15$ 18). However, there is a significant difference in the underlying mechanism of scald burns, which is deeply reflected in socio-economics. In developed countries, for example, scald burns often occur from poorly regulated hot water supply units (2) or when toddlers pull the cord of an electric kettle $(2,6)$. In contrast, in developing countries scald burns frequently occur when children pull at a tablecloth whilst either achieving balance or exploring their environment, after a pot of boiling water or liquid on a fire or stove top at ground level is accidentally knocked over or when they are accidentally bumped into by an adult carrying a container of hot water from 
one room of the home to another $(2,7)$. This latter mechanism of scald injury - being "bumped into by an adult carrying hot water, is also seen in Jamaica. The location in the home in which it occurs however, is unique to that previously described. Previous studies have shown these accidents to occur in the kitchen during food preparation, $(4,7,18)$ whereas, in Jamaica they were just as likely to occur in the corridors of homes, between the kitchen and bathroom, as caregivers carried containers of hot water from the kitchen to the bathroom to prepare the child's bath. This occurs because in many Jamaican households a running hot water supply is not installed, and so water is usually heated in one room [for example the kitchen] and brought to another room for use [for example the bathroom or outdoors for bathing].

Thus, preventive measures which have led to a decrease in the incidence of burn injuries in children in developed countries such as the installation of thermostatic mixers may not be entirely relevant in developing countries $(2,11)$. It is thus, extremely important that every region/country identify its own preventive strategies based on local statistics and data $(2,6,8$, 11, 16-18).

One limitation of this study, is that it only included data from one of the two paediatrics surgical referral centres in urban Jamaica. In addition, the sample size is relatively small. However, data collected from our hospital proved invaluable in identifying risk patterns for the prevention of burns in children in our region.

Suggested preventive measures based on the analysis of data collected during this study include:

- Routine use of table mats instead of tablecloths.

- Securing toddlers in their cot and children in a closed room before transporting hot water or liquids from one room to another during preparation of baths and during meal preparation.

- Using a securely covered container or flask - and not open containers, to transport hot water from one room to another.

- Routinely placing pots and pans with hot water for the warming of feeding bottles towards the back of kitchen tops and counters, away from the reach of toddlers and young children.

- Preferential use of the back burners of stoves.

- Supervised play for all children particularly older boys [five years and above].

- Education programmes for children particularly older boys [five years and above] about the hazards of playing with fire, matches and fireworks.

- National education programmes alerting adults to the danger of leaving children at home alone with lit candles.

- National education programmes alerting adults to the dangers of leaving children unsupervised at the site of fires lit to burn rubbish at the home, a practice which is strongly discouraged (in the rural communities).
- National education programmes for adults on basic burn wound care - to avoid use of hazardous cleansing agents.

With the identification of the above local preventive measures, medical social workers play a fundamental role in their implementation via education programmes for children and parents, and home visits. National radio and television programmes have also been launched in Jamaica during the period of this study, through the Ministry of Youth and Culture, aimed at educating the public about fire hazards and prevention. These programmes have in particular reminded the public that it is a form of child abuse to leave children at home unsupervised (especially with lit candles) and that the practice is an offence which can lead to prosecution.

\section{REFERENCES}

1. Duke J, Wood F, Semmens J, Edgar DW, Spilsbury K, Hendrie D et al. A study of burn hospitalization for children younger than 5 years of age: 1983-2008. Pediatrics 2011; 127: e971-9.

2. Parbhoo A, Louw QA, Grimmer-Sommers K. A profile of hospitaladmitted paediatric burns patients in South Africa. BMC Research Notes $2010 ; 3:$ 165-72.

3. Crandon I, Carpenter R, McDonald A. Admissions for trauma at the University Hospital of the West Indies. A prospective study. West Indian Med J 1994; 43: 117-20.

4. Toon MH, Maybauer DM, Arceneaux LL, Fraser JF, Meyer W, Runge A et al. Children with burn injuries-assessment of trauma, neglect, violence and abuse. J Inj Violence Res 2011; 3: 98-110.

5. Sharma M, Lahoti BK, Khandelwal G, Mathur RK, Sharma SS, Laddha A. Epidemiological trends of pediatric trauma: a single-centre study of 791 patients. J Indian Assoc Pediatr Surg 2011; 16: 88-92.

6. Sheller JL, Thuesen B. Scalds in children caused by water from electri-cal kettles: effect of prevention through information. Burns 1998; 24: 420-4.

7. Drago DA. Kitchen scalds and thermal burns in children five years and younger. Pediatrics 2005; 115: 10-6.

8. Chalya PL, Mabula JB, Dass RM, Giiti G, Chandika AB, Kanumba ES. Pattern of childhood burn injuries and their management outcome at Bugando Medical centre in northwestern Tanzania. BMC Research Notes 2011; 4: 485-94.

9. Mukerji G, Chamania S, Patidar GP, Gupta S. Epidemiology of paediatric burns in Indore, India. Burns 2001; 27: 33-8.

10. Iregbulem LM, Nnabuko BE. Epidemiology of childhood injuries in Enugu, Nigeria. Burns 1993; 19: 223-26.

11. Eadie PA, Williams R, Dickson WA. Thirty-five years of paediatric scalds: are lessons being learned? Br J Plast Surg 1995; 48: 103-5.

12. Nguyen DQ, Tobin S, Dickson WA, Potokar TS. Infants under 1 year of age have a significant risk of burn injury. Burns 2008; 34: 863-7.

13. Williams FN, Herndon DN, Hawkins HK, Lee JO, Cox RA, Kulp GA et al. The leading causes of death after burn injury in a single pediatric burn center. Critical Care 2009; 13: R183. doi: 10.1186/cc8170.

14. Gray O. Demeaned but empowered: the social power of the urban poor in Jamaica. University of the West Indies Press; 2004.

15. Foglia RP, Moushey R, Meadows L, Seigel J, Smith M. Evolving treatment in a decade of pediatric burn care. J Pediatr Surg 2004; 39: 957-60.

16. Lowell G, Quinlan K, Gottlieb LJ. Preventing unintentional scald burns: moving beyond tap water. Pediatrics 2008; 122: 799-806.

17. Van Nierkerk A, Rode A, Laflamme L. Incidence and patterns of childhood burns injuries in the Western Cape, South Africa. Burns 2004; 30: $341-7$.

18. Mercier C, Blond MH. Epidemiological survey of childhood burn injuries in France. Burns 1996; 22: 29-34. 